Agricultural Journal 14 (5): 118-122, 2019

ISSN: 1816-9155

(C) Medwell Journals, 2019

\title{
The Competitiveness of Beef Cattle Breeding Business on Community Livestock-Based in North Penajam Paser Regency, East Kalimantan Province
}

\author{
${ }^{1}$ Muhamad Haslan Mallu, ${ }^{2}$ Dwidjono Hadi Darwanto, ${ }^{2}$ Slamet Hartono and \\ ${ }^{2}$ Jangkung Handoyo Mulyo \\ ${ }^{1}$ Agricultural Service of North Penajam Paser Regency, \\ ${ }^{2}$ Department of Social Economics, Faculty of Agriculture, Gadjah Mada University of Yogyakarta, \\ Yogyakarta, Indonesia
}

\begin{abstract}
The biggest challenge in increasing the population of beef cattle and beef production in Indonesia is on the main actor of beef cattle business, farmers. Farmers as the subject and the main player in livestock business are very important in increasing livestock population and beef production. It is because of $99 \%$ of livestock business in Indonesia is managed by community livestock business. This study aims to measure the level of profit and the competitiveness of beef cattle breeding business in North Penajam Paser Regency. Furthermore, the results of this study are used as a basic consideration of improvement of beef cattle breeding business performance, especially in community livestock-based. The data collection was conducted by using a survey method. Meanwhile, the data analysis was conducted by using qualitative descriptive method and Policy Analysis Matrix (PAM) method. Based on the result, the value of financial analysis is 949,803 IDR per head per period and the value of economy analysis is 86,585 IDR per head per period. The result shows that the business is profitable and feasible. Based on the competitive and comparative advantage analysis, the PCR value is 0.77 and the DCR value is 0.96 it shows that the beef cattle breeding business in North Penajam Paser Regency competitively and comparatively has competitiveness.
\end{abstract}

Key words: Competitive advantage, beef cattle breeding, community livestock breeding, livestock population, beef production, feasible

\section{INTRODUCTION}

The Indonesian agricultural sector has a very strategic role in the national economy for the domestic food needs and being the sector which has most labor. This role will be more difficult to play in the future because the production food capacity is more limited caused by degradation of agricultural land as the effect of land conversion and land use competition.

Beef is one of the food comodities that has contributed to the fulfillment of community nutrition, especially animal protein which support Indonesian human resources. Along with the enhancement of population and improvement of Indonesian's living standard, the demand for the nutritional fulfillment products are also increasing as well as the demand for the foodstuff such as animal protein. According to the Indonesian Statistics in 2014, the enhancement of food demand is caused by large population ( 255 million people in 2014 ) with a high growth rate (1.35\% year) with the estimation of 285 million people in 2025.

The beef demand in Indonesia from year to year is increasing. It is affected by the enhancement of population and the enhancement of their knowledge about the importance of animal protein which influence their consumption pattern. Indonesian Statistics and Directorate General of Livestock and Animal Health Services 2014 estimate that the national beef consumption will reach $1,045 \mathrm{mln}$.ton in 2024 and can be produced domestically for about 546000 tons (52\%) or the shortage is 499000 tons.

In order to achieve the beef self-sufficiency, domestic-scale livestock business improvement program is proved to give significant change, especially for breeders. The beef cattle breeding domestic-scale business is extensively run by using conventional way. In this case, the domestic-scale breeders are able to expand their business with sufficient profits. Market potential and supportive resources are supposed to be an opportunity to develop beef cattle breeding with comparative and competitive advantages in local or export market. Several studies reviewed by Siregar and Ilham (2016) show that Indonesian livestock business provides profits and has comparative advantages.

On the other side, there are several factors affecting difficulty in achieving self-sufficiency. In the upper parts,

Corresponding Author: Muhamad Haslan Mallu, Agricultural Service of North Penajam Paser Regency, Department of Social Economics, Faculty of Agriculture, Gadjah Mada University of Yogyakarta, Yogyakarta, Indonesia 
Agric. J., 14 (5): 118-122, 2019

most of the livestock business is small-scale breeders in which with the 1-3 animal ownership scale is only as saving not a major income the management of livestock is still very simple; livestock productivity is still low. Meanwhile, in the downstream parts are: there are more open marlet which cause imported product/beef cannot be inhibited if there is no good reason there is no integrated industrial activities with cattle fatteing activities. It tends to use imported product because the price is more competitive. In addition, consumer's reference in beef restaurant and supermarket shows that they prefer to buy imported beef with certain reasons (Hasan and Baba 2014).

Based on the beef self-sufficiency, the focus of beef cattle production improvement is on the competitiveness development of livestock continuously. In order to achieve that goal, the policy maker has to consider certain aspects such as processing, marketing and trading, policy of subsidy of input-output and international trade.

In order to understand the condition of competitiveness of beef cattle breeding business, the research on beef cattle breeding competitiveness has to be conducted for analysing profit level, competitive and comparative advantage of the business.

\section{MATERIALS AND METHODS}

This research was conducted in North Penajam Paser Regency of East Kalimantan Province which focus on two sub-districts; Penajam and Sepaku sub-district. The locations were chosen based on purposive sampling mathod as the central area of community-based livestock. The data collection, both primary and secondary were conducted on February-September 2017. The data was collected by using survey method consisting interview, questionnaire and observation by purposively selecting 46 respondents. In addition, the data analysis method was conducted by using policy analysis matrix approach (Table 1). The first line of the policy analysis matrix contains numbers calculated based on private price which means that actual price actually occur in the market is the real price which is accepted or purchased by economic actors. The second line contains calculation of numbers based on social price or shadow price which means that the price describes the real social or economic value for the elements of cost and production.

Input or output social price which is internationally traded can be calculated based on the shadow price by using border price. The type of commodity which is imported is by using C.I.F. price while for the exported one is by using F.O.B. price. It should be noted that various adjustments are required at which point of analysis will be performed. The domestic input price is used as the opportunity cost that is known through this study. The indicator contained in the policy analysis matrix above are financial efficiency and economic efficiency which can be explained as follows:
Table 1: Policy analysis matrix

\section{Cost}

Description Reception Input tadable Input non tradable Profit

\begin{tabular}{lllll}
\hline Private price & A & B & C & D $=$ A-B-C
\end{tabular}

$\begin{array}{lllll}\text { Social price } & E & F & G & H=E-F-G\end{array}$

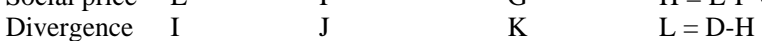

A: Private revenues; G: Cost domestic factors social; B: Cost tradable inputs private; H: Social profits; C: Cost domestic factors private;I: Output transfers; D: Private profits; J: Input transfers; E: Social revenues; K: Factor transfers; F: Cost tradable inputs social; L: Net transfers (Monke and Pearson 1989 and Akhtar et al. 2007)

\section{Financial efficiency/Private Cost Ratio (PCR):}

$$
\mathrm{PCR}=\mathrm{C} /(\mathrm{A}-\mathrm{B})
$$

Where:

$$
\begin{aligned}
& \mathrm{C}=\text { Cost domestic factors private } \\
& \mathrm{A}=\text { Private revenues } \\
& \mathrm{B}=\text { Cost tradable inputs private }
\end{aligned}
$$

Is a private profitability indicator showing ability of the system to pay for fomestic resources and keep being competitive. The system is competitive if the PCR value $<1$, the smaller the PCR value, the more competitive the system.

\section{Economic efficiency Domestic Resource Cost Ratio (DRCR):}

$$
\text { DRCR }=\text { G / (E-F) }
$$

Where:

$\mathrm{G}=$ Cost domestic factors social

$\mathrm{E}=$ Social revenues

$\mathrm{F}=$ Cost tradable inputs social

Is a comparative advantage indicator showing the amount of domestic resources that can be saved to generate one unit of foreign exchange. The system has comparative advantage if the DRC value $<1$, the smaller of the DRC vallue it will be more efficient and has more comparative advantage.

\section{RESULTS AND DISSCUSSION}

Private and social advantage: The input-output structure of beef agribusiness will illustrate cost structure and acceptance of beef cattle breeding business that will explain cost and acceptance components during one fattening period. The element of acceptance in the component of input tradable cost become a larger component of cost compared to input non tradable cost, both private price and social price. The price allocation of input tradable consists of purchase of prospective calf (60.74\%), feed cost/HMT (12.48\%), salt cost $(0.43 \%)$, medicines cost $(0.12 \%)$ and fuel cost $(1.72 \%)$. The input non tradable cost covers labor cost (15.79\%) consisting labor cost of cage cleaning and feeding cattle, meanwhile, labor cost of seeking grass is calculated as beef cattle breeding agribusiness is beef cattle sales. The element of 
Agric. J., 14 (5): 118-122, 2019

Table 2: Cost structure and acceptance of beef cattle breeding in North Penajam Paser Regency (IDR/head/period), 2017

\begin{tabular}{|c|c|c|c|c|c|}
\hline Description & Volume & Private price(Rp.) & Price allocation (\%) & Social price (Rp.) & Price allocation (\%) \\
\hline \multicolumn{6}{|l|}{ Input tradable: } \\
\hline Prospective & 174.12 & $7,835,400$ & 60.74 & $8,205,057$ & 67.03 \\
\hline \multicolumn{6}{|l|}{ Salt and medicines: } \\
\hline Grass (kg/head/period) & 6.441 & $1,610,250$ & 12.48 & $1,535,728$ & 12.55 \\
\hline Salt (kg/head/period) & 15.32 & 55,714 & 0.43 & 20.625 & \\
\hline Medicine (Package/head/period) & 1 & 15,000 & 0.12 & & \\
\hline 3Fuel (Liter/head/period) & 30.36 & 230,736 & 1.79 & 273.240 & 2.23 \\
\hline Sub total & & $9,747,100$ & & $10,049,650$ & \\
\hline \multicolumn{6}{|l|}{$\begin{array}{l}\text { Input non tradable: } \\
\text { Labor (HOK/head/period) }\end{array}$} \\
\hline Cage cleaning & 13.59 & $1,359,000$ & 10.53 & $1,296,078$ & 10.59 \\
\hline Feeding and drinking & 5.91 & 591,000 & 4.58 & 563,637 & 4.60 \\
\hline \multicolumn{6}{|l|}{ Capital (IDR/period) } \\
\hline Interest cost of investment & & 352,209 & 2.730 & 0 & 0.00 \\
\hline Cage and tool shrinkage & & 328,066 & 2.543 & 328,006 & 2.68 \\
\hline Interest cost of working capital & & 511,235 & 3.963 & 0 & 0.00 \\
\hline Taxes & & 9,229 & 0.072 & 0 & 0.00 \\
\hline Land lease (ISR/period) & & 2,628 & 0.020 & 2.592 & 0.02 \\
\hline Sub total & & $3,153,367$ & & $2,190,313$ & \\
\hline Total cost & & $12,900,467$ & 100.00 & $12,239,963$ & 100.00 \\
\hline Cost & 241.00 & $13,850,270$ & & $12,326,548$ & \\
\hline Income & & 949,803 & & 86.585 & \\
\hline
\end{tabular}

Primary data analysis (2017)

cost can be divided into two, namely input tradable covering cost of livestock prospective calf, livestock grass feed, salt and medicines, fuel while input non tradable covering labor costs, land lease, taxes and capital (Table 2).

Livestock grass feed. The interest cost of capital (9.24\%) is the cost for working capital and investment of cage and equipment of beef cattle agribusiness. The calculation of cost of capital interest at private price and social price is different in this study, hence, it resulted different values. The cost of capital interest at private price is calculated from the weighted average of applicable interest of savings in the study area. Meanwhile, for the social price, the cost of capital interest and the interest of investment cost is not included as cost. The cost of prospective calf is the highest allocation price $(60.74 \%)$ of the total cost then followed by cost of labor (15.19\%) and cost of feeding (12.48\%). These results are not different from the study by Lestari et al. (2017) which resulting the highest allocation price of prospective calf (50.67\%) of the total cost; Indrayani et al. (2012) get the allocation price of prospective calf purchase $63.9 \%$ of the total cost of fattening beef cattle. The large percentage of procurement of prospective calf is a major factor of the high production cost. If the price of prospective calf can be suppressed it can be expected that the beef price can be cheaper.

According to the analysis result of private and social advantage (Table 3 ) it is found that the private advantage price is 949,803 IDR which is profitable and feasible. The input tradable cost incurred by breeders coverings prospective calf purchase, livestock grass feed, salt, medicines and fuel cost. Meanwhile, for the input non tradable cost it covers labor cost, working capital and investment capital cost, cage and equipment shrinkage cost and land lease cost. The value of acceptance and
Table 3: Private and social advantage of beef cattle breeding business in North Penajam Paser Regency, 2017

\begin{tabular}{lllll}
\hline & & Input cost & & \\
& & --------------- & \\
Description & Acceptance & Tradable & Non tradable & Advantage \\
\hline Private price & $13,850,270$ & $9,747,100$ & $3,153,367$ & 949,803 \\
Social price & $12,326,548$ & $10,049,650$ & $2,190,313$ & 86,585 \\
Divergence & $1,523,722$ & $-302,550$ & 963,054 & 863,218 \\
\hline \multicolumn{2}{l}{ Primary data analysis (2017) }
\end{tabular}

tradable input cost at the private price is higher than the social price. This is due to the total cost of tradable input paid by breeders is more expensive than the real price (social price). The higher private acceptance is probably caused by the import tariff policy of beef cattle, the imposition of import tariff policy and income tax on tradable input cost. In addition, non-tariff policy in form of import limitation of cattle and beef quota causes the reduction off meat supply especially in Eid al-Adha day when the beef cattle demand is higher than any other days. Similarly, at the private price, the input non tradable cost is higher than the input non tradable cost at social price. It is because of the cost of capital interest and the interest cost of investment and also taxes are calculated as cost while in the social price, those are not calculated as cost.

The beef cattle agribusiness advantage at the social price gives positive value 863,218 IDR which is profitable and feasible. The input tradable cost incurred by breeders is lower than the private price. It is because the price of prospective calf is cheaper than the actual price in which the border price is used at the social price. It is also happened in the input tradable cost and non tradable cost which are cheaper than the actual price. However, at the social price level in which breeders pay cheaper input price than the private price, the social price advanatage obtained by breeders is higher than its acceptance. These 
Agric. J., 14 (5): 118-122, 2019

results are similar to the results from the study by Indrayani et al. (2012) "analysis of fattening beef cattle business production and competitiveness in Agam Regency of West Sumatera” which is profitable both private and social price 1,540,709 IDR (private price) and 503,086 IDR (social price).

Competitive and comparative advantage: The efficiency level of a commodity's procurement can be observed from two indicators namely competitive advantage and comparative advantage. Competitive and comparative advantage are the measure of competitiveness. Competitive advantage is owned at the actual price level received by farmers by using Private Cost Ratio (PCR) indicator. PCR is a private profitability indicator that shows system's ability to pay for domestic resources and keep it to be competitive. Meanwhile, comparative advantage is happened when the market is not distorted by government policies. It can be assessed by using the social price and Domestic Resource Cost Ratio (DRC) indicator. DRC is comparative advantage that shows the amount of domestic resource that can be saved to produce a single unit of foreign exchange (Monke and Pearson, 1989).

Competitive advantage is an indicator to observe if a country will succeed in competing in a commodity of international market. Indicator of private advantage is indicated by Private Cost Ratio (PCR) value which shows system's ability to pay for domestic price and makes it to be competitive on the actual market condition. The smaller the PCR value, the less the domestic price based on actual price required to produce output. If PCR value is $<1$, the commodity system is competitive (Monke and Pearson, 1989). In other words, if PCR value is smaller than one, then the smaller domestic factor price in a single unit is required to increase a single unit of output value added. This means that commodity procurement is financially efficient or has a competitive advantage when there is government policy. Conversely, if PCR value is larger or equal to one, then the larger domestic factor price is required to increase a single unit of output value added.

Domestic Resource Cost Ratio (DRC) is defined as shadow value of domestic input factor used in an activity per unit of tradable value added (Master and Winter-Nelson, 1995). A value of $0<\mathrm{DRC}<1$ shows that the cost of domestic resources at social price is less than output commodity value added, so the commodity that is analysed has comparative advantage. The value of DRC $>1$ shows that the cost of domestic resources at the social price is larger than output value added, so, the commodity does not have comparative advantage.
Table 4: Indicator of competitiveness of beef cattle breeding business in North Penajam Paser Regency, 2017

\begin{tabular}{lc}
\hline Description & Values \\
\hline $\begin{array}{l}\text { Competitive advantage: } \\
\text { Private Cost Ratio (PCR) }\end{array}$ & 0.769 \\
Comparative advantage: & \\
Domestic Resource Cost Ratio (DRC) & 0.962 \\
\hline Primary data analysis (2017)
\end{tabular}

Similarly, if the value of DRC $<0$, the value added that is obtained cannot cover the cost of input domestic, so that, the commodity is not profitable. Monke and Pearson (1989) cited by Master and Winter-Nelson (1995) state that DRC indicator is obtained by dividing the total value of domestic factor on the difference between acceptance and total of input tradable.

Based on the result analysis it is found that beef cattle breeding business in North Penajam Paser Regency has competitive and comparative advantage (Table 4). The PCR value has competitive advantage if it has positive value and smaller than one $(\mathrm{PCR}<1)$. The analysis shows that the PCR value is 0.769 . Competitive advantage can be achieved because it results a single unit of value added which needs 0.769 unit of domestic factor. Meanwhile, the DRC value has comparative advantage which results 0.962 unit of domestic factor.

This result is similar with the study by Yuzaria and Suryadi (2011) on "The analysis of profitability, competitive advantage, comparative advantage and impact of import policy on beef cattle breeding business in west Java Province" in which the PRC value is 0.49 and the DRC value is 0.54 . This study also shows similar result where the DRC value is larger than the PRC value.

The DRC value on the beef cattle fattening business in North Penajam Paser Regency which is larger than the PRC value (DRC>PCR) is suspected that there is government policy that gives incentives or protective to producers of beef cattle breeding. There is an existence of fertilizer subsidies in which can reduce the cost of breeders's production in the provision of forage as animal feed. Another policy is limitation of the amount of beef cattle import. The criteria imported beef cattle are the weight is $<350 \mathrm{~kg}$ and the beef cattle should comes from countries free of primary contagious animal diseases.

\section{CONCLUSION}

The researcher concludes that first, the process of fattening beef cattle in North Penajam Paser Regency by the breeders is still using traditional pattern which is characterized by the application of cattle breeding 
management managed by using simple way without using any available technology second, this business has competitiveness by indicator analysis of the advantage has positive value both financially or economically which means that it is profitable and third, the business runs efficiently and has competitiveness both on competitive advantage or comparative advantage. However, the comparative advantage is still weak because the DRC value approaches one.

\section{SUGGESTIONS}

The researcher has some suggestions for the progress of beef cattle breeding in North Penajam Paser Regency. The government should apply input subsidy and output price protection in order to improve productivity and competitiveness of beef cattle breeding. In addition, the government also should encourage the implementation of beef cattle breeding technology to breeders in order to maximize productivity which can increase the competitiveness itself.

\section{REFERENCES}

Akhtar, W., M. Sharif and N. Akmal, 2007. Analysis of Economic efficiency and competitiveness of the rice production systems of Pakistans Punjab. Lahore J. Econ., 12: 141-153.
Hasan, S. and S. Baba, 2014. [Cattle development model based on peoples livestock in supporting national beef private programs]. Master Thesis, Fakultas Peternakan Universitas Hasanuddin, Makassar, Indonesia. (In Indonesian)

Indrayani, I., R. Nurmalina and A. Fariyanti, 2012. [Technical efficiency analysis of beef cattle fattening business in Agam Regency, West Sumatra Province (In Indonesian)]. Indonesian Anim. Husbandry J., 14: 286-296.

Lestari, R.D., L.M. Baga and R. Nurmalina, 2017. [Competitiveness of fattening beef cattle farming business in bojonegoro regency (In Indonesian)]. Bull. Anim. Sci., 41: 101-112.

Masters, W.A. and A. Winter-Nelson, 1995. Measuring the comparative advantage of agricultural activities: Domestic resource costs and the social cost-benefit ratio. Am. J. Agric. Econ., 77: 243-250.

Monke, E.A. and S.R. Pearson, 1989. The Policy Analysis Matrix for Agricultural Development. Cornell University Press, Ithaca, New York, USA., Pages: 279.

Siregar, M. and N. Ilham, 2016. [Efforts to improve livestock business efficiency in terms of competitive agribusiness aspects (In Indonesian)]. Agro Econ. Res. Forum, 21: 57-66.

Yuzaria, D. and D. Suryadi, 2011. [Profit level analysis, competitive advantage, comparative excellence and import policy impacts on beef cattle business in West Java Province (In Indonesian)]. Jurnal Agripet, 11: 32-38. 